\title{
PERAN KIAI DALAM REKONSILIASI SOSIAL PASCA CAROK MASSAL DI BUJUR TENGAH PAMEKASAN MADURA
}

\author{
Ismail dan Moh Wardi \\ STAI Nazhatut Thullab Sampang \\ Jl. Diponegoro No. 11 Sampang Madura \\ Email: yajlisismail@gmail.com dan mohwardi84@gmail.com
}

Abstract: This research is a case study conducted in the Central Bujur of Bat umarmar District, Pamekasan Regency Madura. In some cases of carok in Madura, it is often followed by follow-up carok, but due to the role kiai, the carok that occurs in Central Bujur is unique because there is no subsequent carok like other carok. This study is to answer the research focus: (1) What is the role of kiai in social reconciliation post-mass carok in the Central Bujur of Pamekasan Madura, and (2) What is the model of social reconciliation in resolving the social conflict post-mass carok in the Central Bujur of Pamekasan Madura. In collecting data, the researchers agreed to interviews and documentation, while data analysis was carried out by data reduction techniques, data purification, verification and conclusions. From the data analysis, findings were obtained: (1) in the reconciliation kiai play a role as a reference, as a conceptor, as a negotiator and mediator, as well as an executor. (2) a model of social reconciliation based on the theory of human needs theory using economic, religious, and socio-cultural approachs.

Keywords: Kiai, reconciliation, carok

Abstrak: Penelitian ini merupakan studi kasus persitiwa carok massal yang terjadi di Desa Bujur Tengah Kecamatan Batumarmar Kabupaten Pamekasan Madura. Pada beberapa kasus carok di Madura, sering kali diikuti dengan dengan carok susulan (balasan), namun karena adanya peran kiai maka carok yang terjadi di Bujur Tengah ini menjadi unik karena tidak ada carok susulan seperti carok lainnya. Studi ini untuk menjawab fokus peneltiian: (1) Bagaimana peran kiai dalam rekonsiliasi sosial pasca carok massal di Bujur Tengah Pamekasan Madura, dan (2) Bagaimana model rekonsiliasi sosial dalam penyelesaian konflik sosial pasca carok massal di Bujur Tengah Pamekasan Madura. Dalam pengum- 
Ismail dan Moh Wardi: Peran Kiai dalam Rekonsiliasi Sosial Pasca Carok Massal di Bujur Tengah Pamekasan Madura (hal. 128-152)

pulan data, peneliti menerapkan tehnik wawancara dan dokumentasi, sedangkan analisis data dilakukan dengan teknik reduksi data, penyejian data, dan verifikasi dan pengambilan kesimpulan. Dari analisis data diperoleh temuan: (1) dalam rekonsiliasi kiai berperan sebagai rujukan, sebagai konseptor, sebagai negosioator dan mediator, dan juga sebagai ekskutor. (2) model rekonsiliasi sosial merujuk pada teori human needs theory dengan pendekatan ekonomi, religius, dan sosial-budaya

Kata kunci: Kiai, rekonsiliasi, carok.

\section{A. Pendahuluan}

Carok bagi masyarakat Madura bukanlah sesuatu yang baru, karena carok merupakan peristiwa yang terjadi sejak zaman dahulu. Menurut Latief Wiyata, carok sebagai akibat dari tidak dilakukannya kontrol secara langsung oleh penjajah Belanda (VOC) terhadap wilayah kekuasaannya di Madura, "Akhirnya, setiap orang menyelesaikan persoalannya sendiri-sendiri. Salah sat unya dengan carok." (Majalah Tempo, 2006). Oleh karenanya, carok menjadi media tersendiri bagi masyarakat Madura dalam menyelesaikan masalah-masalah tertentu. Bahkan lebih lanjut menurut A. Latief Wiyata, dari 1990 sampai 1994, sebanyak 60,4 persen carok di daerah itu terjadi karena istri mereka diganggu lelaki lain, 16,9 persen lantaran salah paham, 6,7 persen karena konflik tanah warisan, dan 9,2 persen dipicu utang-piutang (Majalah Tempo, 2006). Tapi yang berbeda pada carok massal yang terjadi di Desa Bujur Tengah Kecamatan Batumarmar Kabupaten Pamekasan, karena dalam peristiwa carok ini melibatkan banyak orang baik pelaku maupun korbannya. Carok ini terjadi pada hari Rabu tanggal 12 Juli 2006. Dalam carok ini tidak kurang dari 150 orang terlibat, terdapat korban 7 (tujuh) orang meninggal dan 9 (sembilan) orang lainnya luka-luka. Carok ini terjadi karena konflik antara mantan Kepala Desa (H. Baidowi) dan Kepala Desa Terpilih (H. Mursyidin) tentang peguasaan tanah percaton atau tanah kas desa (Antaranews, 2016). Karena yang berkonflik ini berlatar kepala desa maka akibatnya melibatkan orang lain sebagai pendukungnya, sehingga terjadilah carok massal tersebut.

Di sisi lain, carok massal sesungguhnya tidak hanya terjadi di wilayah Kabupaten Pamekasan, setiap daerah di Madura pernah memiliki peristiwa carok massal. Di Bangkalan terjadi carok massal pada 28 Juli 2015, tepatnya di Desa Berbeluk, Kecamatan Arosbaya. Dalam tragedi ini 2 korban tewas 
dan 5 orang lainnya luka-luka (Okezonenew, 2015). Begitu pun di Sampang, pernah terjadi carok massal pada 14 April 2015 di Desa Sokobanah Daya Kecamatan Sokobanah (Antaranews, 2016). Tak luput juga di Sumenep terjadi carok massal pada 6 Oktober 2009 dengan korban 4 orang mengalami luka bacok (Okezonenew, 2015).

Yang menarik dalam peristiwa ini (carok massal Bujur Pamekasan) adalah karena melibatkan banyak pihak, atau orang lain yang tidak berkepentingan atas obyek yang diperebutkan antara $\mathrm{H}$. Baidowi dan $\mathrm{H}$. Mursyidin. Sehingga terjadilah konflik sosial sebagai akibat dari keterlibatan masyarakat dalam sebuah permasalahan. Oleh karena itu, maka permasalah awal perebutan tanah percaton sebagai masalah pribadi antara kedua pihak yang berselisih kemudian bergeser menjadi permasalahan sosial, sehingga konflik yang terjadi menjadi konflik sosial. Dalam kasus carok massal ini, dapat diasumsikan bahwa setelah carok massal itu akan terjadi konflik sosial lebih lanjut. Konflik sosial tersebut merupakan masalah-masalah yang terkait dengan keterlibatan banyak orang dalam sebuah permasalahan. Dan dalam tradisi carok di Madura, terjadi terus menerus karena balas-membalas, hingga beberapa generasi.

Namun, tidak demikian dengan dengan carok massal di Bujur Pamekasan ini, karena hingga tahun 2015 berakhir tidak terdengar kabar adanya carok lanjutan dari carok massal yang terjadi pada 12 Juli 2006 tersebut. Menurut sebagian informasi yang dapat dipercaya, hal itu dikarenakan adanya keterlibatan beberapa kiai (tokoh pondok pesantren) di wilayah Pemekasan dalam upaya mendamaikan kedua kubu yang berselisih, serta kesepakatan atas diprosesnya para pelaku secara hukum oleh yang pihak yang berwenang (Siddiq, 2016). Beberapa kiai pesantren yang terlibat dalam uapaya perdamaian tersebut antara lain Pondok Pesantren Mambaul Ulum Bata-Bata, Pondok Pesantren Darul Ulum Banyuanyar, Pondok Pesantren Al-Mujtama' Plakpak, Pondok Pesantren Miftahul Ulum Panyepen, Pondok Pesantren Miftahul Ulum Bittet, dan beberapa pesanntren lain (Hasanuddin, 2016). Maklum saja, karena masyarakat Bujur Pamekasan 90\% (sembilan puluh persennya) berpendidikan pesantren.

Dari fakta dan informasi tersebut kami berencana mengadakan penelitian dengan judul "Peran Kiai dalam Rekonsiliasi Sosial Pasca Carok Massal di Bujur Pamekasan Madura", dengan maksud untuk mengetahui lebih lanjut 
Ismail dan Moh Wardi: Peran Kiai dalam Rekonsiliasi Sosial Pasca Carok Massal di Bujur Tengah Pamekasan Madura (hal. 128-152)

keterlibatan kiai dalam penyelesaian konflik sosial dan akibat carok massal di desa Bujur Tengah Pamekasan Madura.

\section{B. Peristiwa Carok Massal Di Bujur Tengah Pamekasan MAdura}

Carok massal, merupakan carok yang melibatkan banyak orang. Carok merupakan tradisi bertarung yang disebabkan karena alasan tertentu yang berhubungan dengan harga diri kemudian diikuti antar kelompok atau antar klan dengan menggunakan senjata (biasanya celurit) (Wiyata, 2002). Adapun menurut kamus bahasa Madura Indonesia, carok adalah berkelahi satu lawan satu at au berkelompok dengan memakai senjata tajam sehingga salah satu ada yang mati atau mati keduanya at au minimal terluka (Pawitra, 2009: 105). Jadi, karakter dari carok ini adalah menggunakan senjata tajam. Carok hanya dipakai oleh orang Madura untuk mengistilahkan praktik pembunuhan atau melukai orang lain dengan menggunakan senjata tajam (Jonge, 2011: 127). Carok merupakan bagian dari kekerasan, karena dalam peristiwa carok megakibatkan terjadinya kekerasan fisik. Carok terjadi tidak hanya antara dua orang, bahkan terdapat carok yang melibatkan banyak orang dalam sebuah gelanggang pertarungan. Kondisi inilah yang disebut dengan carok masal yang banyak terjadi di masyarakat Madura dan berbeda dengan kekerasan masal yang terjadi di tempat lain, bahkan carok disebut sebagai arena reproduksi kekerasan dan pencetus spiral kekerasan baru (Wiyata, 2002: 23).

Dalam konteks peristiwa carok massal di Bujur Tengah, dapat dipahami bahwa carok massal merupakan carok yang melibatkan banyak orang, bukan hanya duel satu lawan satu. Disebut pula carok massal karena peristiwa carok di Bujur Tengah ini terjadi dalam satu waktu dan melibatkan banyak orang serta menelan lebih dari satu korban. Kedua pihak (H. Baidlowi dan H. Mursyidin) sama jatuh korban.

Carok massal itu terjadi berawal dari konflik pribadi antara H. Baidlowi dan H. Mursyidin. Konflik kedua orang ini berawal dari rivalitas dalam pemilihan kepala desa Bujur Tengah yang akhirnya dalam pemilihan itu dimenangkan oleh H. Mursyidin. Namun, seusai pemilihan kepala desa H. Baidlowi tidak menerima kekalahan itu, sehingga beberapa tindakan pun dilakukannya sehingga memicu terjadi konflik. Yang paling pokok dalam memicu terjadinya konflik adalah $\mathrm{H}$. Baidlowi tidak mau menyerahkan tanah catoh kepada H. Mursyidin selaku kepala desa menjabat. 
Keengganan H. Baidlowi untuk menyerahkan tanah catoh kepada $\mathrm{H}$. Mursyidin bukan tanpa alasan, karena menurut pihak H. Baidlowi, tanahtanah yang dulunya dia terima sebagai catoh, sekarang sudah berubah menjadi hak miliknya dan beberapa warga. H. Baidlowi mengklaim telah melakukan tukar guling terhadap 5,4 Ha tanah catoh desa tersebut. Klaim itu, menurut H. Baildowi, telah sesuai dengan peraturan yang berlaku, dan sebagai buktinya adalah adanya persetujuan dari Pemerintah Provinsi Jawa Timur pada saat tukar guling itu dilakukan.

Namun, pihak H. Mursyidin tidak menerima atas kenyataan tanah catoh it u yang dikuasai dan bahkan dianggap dimiliki oleh pribadi-pribadi warga desa. Menurutnya, tanah catoh adalah tanah kas desa, aset desa, tidak dapat dimiliki secara pribadi, serta tukar guling yang dilakukan oleh $\mathrm{H}$. Baidlowi bertentangan dengan perat uran yang berlaku. Kalaupun benar tukar guling yang dilakukan oleh $\mathrm{H}$. Baildowi mendapatkan persetujuan dari Pemerintah Provinsi Jawa Timur, ditengarai prosesnya tidak prosedural. Jelas saja, kemdian pihak H. Mursyidin menemukan indikasi pemalsuan tanda tangan beberapa pihak dalam proses administrasi tukar guling kala itu. Oleh karenanya, maka pihak H. Mursyidin memperkarakan H. Baidlowi atas indikasi pemalsuan tanda tangan itu. Maka dalam proses pengadilan, H. Baidlowi dinyatakan bersalah dan divonis 8 bulan penjara.

Konflik pun terus berlanjut. Setelah H. Baidlowi bebas dari hukuman penjara, dia kemudian memperkarakan H. Mursyidin atas dugaan penyelewengan bantuan beras untuk masyarakat miski (raskin). Pihak H. Baidlowi menuduh $\mathrm{H}$. Mursyidin tidak mendistribusikan bantuan bersa miskin kepada warga desa penerima bantuan itu. Menurut H. Baidlowi, beras bantuan untuk masyarakat miskin hanya dinikmati oleh $\mathrm{H}$. Mursyidin. Kasus ini pun sampai di meja hijau. Namun, dalam persidangan H. Mursyidin dinyatakan tidak bersalah, karena $\mathrm{H}$. Mursyidin tidak terbukti menyelewengkan bantuan beras miskin.

Sementara konflik terus berlanjut, dan tidak ada kesepakat an penyelesaian sengketa tanah catoh. Tanah catoh yang sudah menjadi hak milik beberapa warga tetap tidak bisa kembali ke kas desa. Hal ini kemudian menyebabkan para pendukung $\mathrm{H}$. Mursyidin semakin menuntut kepada $\mathrm{H}$. Mursyidin untuk mengambil paksa tanah catoh tersebut. Para pendukung $\mathrm{H}$. Mursyidin yang menuntut untuk mengambil paksa tanah catoh adalah mereka 
Ismail dan Moh Wardi: Peran Kiai dalam Rekonsiliasi Sosial Pasca Carok Massal di Bujur Tengah Pamekasan Madura (hal. 128-152)

yang berperan aktif dan besar kontribusi dukunganya kepada $\mathrm{H}$. Mursyidin dalam keterpilihannya sebagai kepala desa. Di antara mereka ada yang menjabat sebagai kepala dusun (apel), yang lumrahnya mendapatkan bagian mengelola pertanian tanah catoh, dan hasilnya menjadi konpensasi atas dukungan yang diberikan, dan juga karena aparatur desa tidak mendapatkan gaji maupun honorarium yang layak dari pemerintah. Sehingga, tanah catoh itu kemudian menjadi strategis sebagai sumber ekonomi para aparatur desa. Oleh karenanya, sangatlah wajar ketika para pendukung kuat $\mathrm{H}$. Mursyidin bersikeras untuk mendapatkan tanah catoh yang ditukar guling oleh $\mathrm{H}$. Baidlowi itu. Sementara tanah pengganti dari tukar guling itu, dianggap tidak produktif karena bukan lahan pertanian, melainkan tanah tandus yang tidak bisa ditanami padi, jagung, apa lagi tembakau.

Tuntutan yang semakin hari semakin menguat dari para pendukung, membuat $\mathrm{H}$. Mursyidin harus terus berusaha untuk mendapatkan kembali tanah catoh itu. Kemudian H. Mursyidin berupaya melakukan pendekat an kepada pihak H. Baidlowi dengan perantara pihak Kecamatan Batumarmar. Upaya itu pun dilakukan. Pertemuan dan perundingan dilakukan, baik antara pihak kecamatan dengan pihak H. Baidlowi dan H. Mursyidin. Namun, upaya perundingan it u pada akhirnya tidak membuahkan hasil. Pihak H. Baidlowi tetap bersikukuh pada apa yang telah diyakininya. Mereka tetap berpegang pada hasil proses tukar guling yang telah selesai sejak waktu sebelum adanya suksesi kepala desa. Sementara pihak H. Mursyidin terus menunt ut agar tanah catoh dkembalaikan ke kas desa, karena proses tukar guling cacat hukum. Atas ketegangan itu, pihak kecamatan Batumarmar pun tidak mempu bertindak lebih lanjut.

Pada saat berikutnya, ketegangan antar pihak pun semakin kuat. Polarisasi masyarakat pun semakin nampak. Masyarakat kemudian terpecah menjadi beberapa kelompok. Ada kelompok pro H. Baildowi, ada pula yang pro $\mathrm{H}$. Mursyidin, dan ada pula yang tidak memihak. Mereka yang pro $\mathrm{H}$. Baidlowi merupakan para pemegang tanah catoh, dan sekali gus pendukung $\mathrm{H}$. Baidlowi dalam pemilihan kepada desa. Sedangkan yang pro $\mathrm{H}$. Mursyidin adalah para pendukung H. Mursyidin dalam pemilihan kepala desa, yang secara umum saat itu menjabat aparatur pemerintahan desa. Sementara mereka yang tidak memihak adalah mereka yang memang berusaha unt uk tidak ikut terlibat dalam konflik it $u$, meskipun di antara mereka ada yang mendapatkan tanah catoh. 
Dalam kondisi itu, desa terlihat dalam situasi konflik. Cekcok mulut antar pihak sering terjadi. Perdebatan-perdebatan seputar tanah catoh pun sering menjadi konsumsi masyarakat di beberapa tempat terbuka. Hingga akhirnya suhu konflik memuncak. Masing-masing kelompok saling menggunjing, saling menyinggung, saling menyalahkan. Artinya, di saat itu, konflik pun menjadi terbuka.

Sebagaimana pada umumnya masyarakat Madura, masyarakat desa Bujur Tengah melihat bahwa konflik yang tidak dapat diselesaikan dengan cara diskusi kekeluargaan, maka penyelesaiannya dengan adu fisik. Adu fisik bagi masyarakat Bujur Tengah tiada lain kecuali carok. Maka dari itu, terjadilah carok massal itu pada hari Rabu tanggal 12 Juli 2006.

\section{Peran Kiai dalam Rekonsiliasi Sosial Pasca Carok Massal di Bujur Tengah Pamekasan Madura}

Menurut data yang peneliti peroleh dari lapangan, ada beberapa peran yang ditampilkan oleh kiai dalam proses rekonsiliasi sosial pasca carok massal di Bujur Tengah. Peran itu antara lain; kiai sebagai rujukan, kiai sebagai inspirator, kiai sebagai negosiator dan mediator, serta kiai sebagai ekskutor. Peran-peran itu dapat dijelaskan sebagai berikut.

\section{Kiai Sebagai Rujukan (MarobbHU Ka КEAEH)}

Untuk memhami peran kia sebagai rujukan masyarakat Bujur Tengah, perlu dijelaskan falsafah masyarakat Madura tentang posisi kiai. Masyarakat Bujur Tengah memiliki pegangan falsafah "marobbhu ka keaeh". Falsafah ini secara harfiah berarti "menyerahkan segalanya kepada kiai". Konsep falsafah ini merupakan turunan dari falsafah pokok "bhepak bhebu guru ratoh". Yang maknanya adalah menurut masyarakat Madura ada tiga (pihak) orang yang wajib ditaati, yakni bapak dan ibu (orang tua), guru (pendidik), dan penyeleggara negara. Masyarakat Madura melihat ketiga (pihak) orang ini adalah orang yang harus dipatuhi, ditaati, diikuti, dan dihormati. Bapak dan ibu merupakan orang tua yang telah menyebabkan seorang anak lahir dan hidup di dunia. bapak dan ibu adalah orang yang merawat dan menjaga hidupnya sehingga mencapai kehidupan dewasa secara fisik. Mereka menyebabkan seorang anak mampu hidup dan bertahan dalam kehidupan di dunia. Tidak terhitung jasa bapak dan ibu bagi seorang anak. Oleh karenanya, maka terhadap bapak dan ibu, seorang anak diwajibkan taat, patuh, hormat, sayang, 
Ismail dan Moh Wardi: Peran Kiai dalam Rekonsiliasi Sosial Pasca Carok Massal di Bujur Tengah Pamekasan Madura (hal. 128-152)

dan selalu berbuat baikk terhadap mereka, bahkan sampai mereka tiada pun, kewajiban berbuat baik kepada mereka tetap harus dilakukan.

Yang kedua guru. Guru merupakan orang yang telah memberikan petunjuk melalui proses penidikan, baik formal, nonformal, maupun informal. Salah satu dari guru itu adalah kiai. Kiai yang merupakan guru atau bahkan maha guru di sebuah pesantren dianggap guru oleh masyarakat Madura, meskipun mereka tidak secara langsung menimba ilmu dari kiai yang bersangkutan. Misalkan, karena anaknya sasja mondok di sebuah pesantren, maka si orang tua akan menganggap sang kiai sebagai guru bagi dirinya juga. Sehingga apa yang dilakukan anaknya sebagai santri sang kiai, akan dilakukan juga oleh si orang tua. Seperti taat, patuh, hormat dan lain sebagainya.

Yang ketiga pemimpin/penguasa/penyelenggara negara at au pemerintahan. Masyarakat Madura berpegang pada prinsip bahwa pemimpin/ penguasa/penyelenggara harus ditaati, dipatuhi, dihormati, karena pihak ini adalah penent u keterat uran dalam kehidupan dunia, yang berimplikasi terhadap kehidupan mereka di akhirat kelak. Tent unya, selain dari dasar logika di atas, masyarakat Madura berperilaku demikian juga karena adanya ajaran agama Islam mengenai kewajiban taat kepada ketiga (pihak) orang ini.

Dari ketiga (pihak) orang ini, kiai memiliki posisi paling sakral. Bahkan posisi kedua (pihak) orang yang lain - orang tua dan pemimpin - pada suatu saat digantikan oleh kiai. Hal ini artinya, ketaatan masyarakat Madura kepada kiai dapat menafikan ketaatan mereka kepada kedua (pihak) orang yang lain. Dalam kehidupan masyarakat di Indonesia, keberadaan kiai diposisikan dalam kelompok atas dalam struktur masyarakat. Kiai ditempatkan sebagai tokoh, yang karena dianggap memiliki kelebihan dalam hal ilmu pengetahuan agama dan kebijaksanaan, seringkali didatangi dan dimintai nasihat. Dalam kehidupan masyarakat modern, beberapa fungsi dari psikolog dalam hal layanan konsultasi terdapat dalam peran kiai terhadap lingkungan sekitarnya (Achidsti, 2014: 150).

Pemikiran ini memiliki dasar argumentasi bahwa kiai merupakan satu kesatuan dari orang tua, guru, dan pemimpin. Kiai menjadi orang tua, menjadi guru, dan menjadi pemimpin sekaligus. Hal ini karena peran kiai dalam membimbing kediupan masyarakat memang tidak terbatas oleh waktu dan tempat. Jika orang tua cenderung pada pemenuhan kebut uhan fisik jasmani saja, tapi kiai lengkap antara fisik jasmani dan psikis ruhani. Jika pemipin/ 
penguasa/penyelenggara negara terbatas pada waktu dan sisi administrasi, tetapi kiai melayani seluruh sisi dan ranah kehidupan masyarakat. Oleh karenanya, posisi kiai dapat melampaui posisi (pihak) orang yang lain.

Dari persepsi tentang posisi kiai itu, kemudian konsktruksi persepsi masyarakat tentang peran kiai bagi kehidupan sosial masyarakat terbangun. Warga desa telah membangun tradisi tersendiri mengenai peran kiai. Warga desa melihat bahwa peran kiai tidak terbatas oleh ruang dan waktu. Segala hal dapat - harus - dikomunikasi kepada kiai. Dengan ini, maka terbentuklah tradisi warga desa untuk selalu menyampaikan berbagai hal yang berkaitan dengan kehidupan mereka kepada kiai. Warga desa terbiasa datang ke kiai untuk sekedar mendapatkan do'a, untuk meminta pendapat tentang tanggal pelaksanaan hajatan tertentu, dan juga untuk mengetahui stat us hukum tertentu, atau bahkan hanya sekedar menghantarkan beberapa hasil pertanian kepada kiai, seperti jagung, padi atau beras, ketela dan selain sebagainya dari palawija yang dihasilkan dari pertanian mereka. jika dalam masyarakat tertentu telah terdapat tokoh yang dituakan yang menempati posisi dalam struktur adat dan tradisi setempat. Bisa pula sebuah bagian di masyarakat yang biasanya mengurus persoalan tertentu seperti perkumpulan, rapat atau musyawarah yang akan memutuskan jawaban persoalan penting yang berfungsi seperti sebuah mahkamah/dewan, dan sejenisnya. Tidak jarang ditemui bahwa seorang kiai biasanya memegang posisi dalam suatu struktur lembaga adat di desa bersangkut an Achidsti, 2014: 152).

Dari falsafah "bhepak bhebuh guru ratoh" kemudian dihasilkan pemikiran "marobbhu ka keaeh". Pemikiran ini memiliki makna bahwa Warga desa memiliki tradisi pasrah sepenuhnya kepada kiai dalam segala urusan. Karena segala hal yang akan dilakukan oleh warga desa pasti akan dikomunikasikan dengan kiai, pasti didiskusikan terlebih dahulu dengan kiai, atau pasti menunggu petunjuk kiai. Kiai juga seringkali berada dalam posisi pemimpin, entah itu secara administratif atau simbolik atau juga keduanya, maka kultur agama Islam adalah aspek yang turut menjadi pelanggeng posisi kiai pada atap struktur sosial (Achidsti, 2014: 158-159).

Menurut warga desa Bujur Tengah, tidak ada batasan dan ukuran dari suatu untuk mendapatkan pet unjuk kiai. Setiap keperluan, kecil maupun besar, selalu atas perkenan dari kiai. Hal ini bukan tanpa alasan, karena warga desa memiliki persepsi bahwa kiai adalah (pihak) orang yang selalu siap siaga untuk 
Ismail dan Moh Wardi: Peran Kiai dalam Rekonsiliasi Sosial Pasca Carok Massal di Bujur Tengah Pamekasan Madura (hal. 128-152)

warga desa. Kiai senantiasa bersedia mendengarkan keluh kesah warga desa, selalu bisa memahami situasi dan kondisi yang sedang dihadapi oleh warga desa. Sehingga warga desa merasa sangat dekat dengan kiai. Tingkat kepatuhan orang Madura pada ajaran agamanya menjadi keung-gulan sekaligus modal untuk meneguh-kan kehidupan masyarakat yang religius. Selain tingkat kepatuhannya pada kiai, religiusitas orang Madura juga tergambar dari tingginya semangat keagamaan yang tampak dalam kegairahan menyelengga-rakan ritual-ritual agama, banyaknya institusi pendidikan Islam (pesantren dan madrasah), padatnya jumlah masjid dan mushalla, bahkan di hampir tiap rumah di Madura terdapat langgar, dan lain sebagainya (Syarif, 2014: 116).

Dalam konteks penyelesaian konflik sosial, kiai kerap kali menjadi sandaran pihak yang berkonflik. Bahkan dua orang yang sedang berselisih at au berkonflik, bisa sama-sama menghadap seorang kiai, meskipun tidak dalam waktu yang sama. Hal ini dikarenakan sikap netral kiai dalam menengahi suat u konflik yang terjadi. Warga desa berkeyakinan bahwa kiai tidak akan pernah memihak kepada siapaun, kiai tetap kokoh berdiri di atas kebenaran. Warga desa juga berprinsip bahwa kiai tidak akan pernah mengambil keunt ungan dalam bentuk apapun atas penyelesaian suat u konflik. Oleh karena sifat dan sikap kiai yang demikian, maka kiai selalu pro kepada warga desa, dan begitu pula sebaliknya, warga desa senantiasa pro kepada kiai. Warga desa tidak akan pernah bersilang pendapat dengan kiai.

Dalam konteks penyelesaian konflik sosial pasca carok massal di Bujur Tengah, realit as itu pula yang terjadi. Sesungguhnya, setelah carok massal itu terjadi, kedua pihak yang bersengketa dan terlibat dalam carok massal itu, seluruhnya sama-sama datang dan mengadu kepada kiai, meskipun tidak kepada satu kiai saja. Karena mereka memiliki hubungan emosional yang kuat kepada kiai tertentu. Kuatnya hubungan emosional kepada kiai tertentu itulah yang mendorong pihak dari $\mathrm{H}$. Baidlowi dan $\mathrm{H}$. Mursyidin datang kepada kiai, menceritakan segala hal yang terjadi, dan menyampaikan keinginan mereka untuk penyelesaian konflik itu. Hubungan emosional ini terbentuk oleh beberapa faktor. Namun faktor yang sangat dominan adalah hubungan kesantri-an. Artinya, sesorang akan lebih dekat hubungannya kepada seorang kiai yang ia pernah mengaji langsung kepadanya. Secara singkat dapat dikatakan bahwa alumni pesantren tertentu memiliki hubungan emosional yang sangat kuat dengan pengasuh pesantren itu. 
Kedua pihak yang berkonflik menyampaikan keluh kesah dan keinginannya untuk berdamai kepada kiai menurut kedekatannya. Yang memiliki hubungan emosional dengan Pesantren Bringin Angsanah, akan menyampaikan semuanya kepada kiai Ali Salim. Yang alumni Pesantren Darul Banyuanyar komunikasinya dengan kiai Muhammad Syamsul Arifin. Yang alumni Pesantren Mambaul Ulum Bata-Bata mengadunya kepada kiai Abdul Hamid. Dan begitu pula bagi yang alumni pesantren al-Mujtama' Plakpak dan lain sebagainya. Jadi, kiai-kiai tersebut dan kiai lainnya merupakan rujukan bagi warga desa Bujur Tengah.

\section{Kiai Sebagai Konseptor}

Ketika para kiai telah mendapatkan informasi yang lengkap mengenai berbagai hal yang terkait dengan persitiwa carok massal di Bujur Tengah, maka kemudian para kiai memutuskan untuk berdiskusi untuk membicarakan keinginan masyarakat untuk berdamai. Beberapa pertemuan para kiai dilaksanakan dan dihasilkan beberapa keputusan. Kiai merupakan perekat solidaritas dan kegiatan ritual keagamaan, pembangun sentimen kolek-tif keagamaan dan penyatu elemen-elemen sosial atau kelompok kekerabat an yang tersebar karena faktor-faktor eko-logis dan struktur pemukiman (Kuntowijoyo, 2002: 85-87).

Dalam penyusuan konsep ini, para kiai juga melibatkan pihak lain; pemerintah kecamatan Batumarmar dan kabupaten Pamekasan, kepolisian dan TNI di wilayah pamekasan. Para kiai melakukan pertemuan antar kiai, pertemuan kiai dengan pihak penegak hukum, pertemuan kiai dengan pemerintah daerah, pertemuan kiai dengan warga desa Bujur Tengah pun dilakukan. Dalam pertemuan-pertemuan itu para kiai membahas beberapa ide dalam rangka mencari solusi untuk mendamaikan kedua pihak yang berkonflik. Semua ide yang ditawarkan mengacu pada informasi yang diterima para kiai dari warga desa Bujur Tengah. Informasi yang sangat penting bagi para kiai adalah bahwa warga desa Bujurt Tengah seluruhnya merasa menyesal at as peristiwa yang memakan korban jiwa tersebut, warga desa Bujur Tengah seluruhnya berkeinginan untuk damai dan hidup seperti sedia kala, dan warga desa Bujur Tengah menyerahkan segala proses perdamaian itu kepada para kiai.

Oleh karena itu, setelah menghimpun informasi sebanyak-banyaknya nengenai perstiwa carok massal itu, para kiai memadukan pemikiran- 
Ismail dan Moh Wardi: Peran Kiai dalam Rekonsiliasi Sosial Pasca Carok Massal di Bujur Tengah Pamekasan Madura (hal. 128-152)

pemikiran yang dimiliki oleh masing-masing kiai guna menemukan jalan keluar berupa tindakan konkrit untuk memulai mendamaikan para pihak yang berkonflik. Diskusi dan perundingan terus dilaksanakan oleh para kiai dengan pembahasan pokok menemukan konsep praktis dalam usaha rekonsiliasi masyarakat yang telah tercerai berai akibat konflik yang mendera mereka.

Dari berbagai dan beberapa diskusi dan perundingan yang dilaksanakan, para kiai menemukan rumusan langkah rekonsiliasi. Langkah tersebut, menurut para kiai, merupakan langkah praktis-strategis dalam upaya mencapai perdamaian di tengah-tengah warga desa. Rumusan langkah tersebut pula merupakan konsep penyelesaian konflik warga desa yang dianggap konferhensif dan fundamental. Rumusan langkah itu pula merupakan keput usan yang diambil dengan berdasar pada berbagai pertimbangan menurut data atau informasi yang dihimpun oleh masing-masing kiai. Keput usan yang diambil menyangkut; (1) mencari akar masalah penyebab carok massal; (2) berunding dengan warga desa untuk proses perdamaian; (3) "membeli" tanah catoh; (4) mengadakan koloman rutin; dan (5) mendamaikan warga. Lima konsep inilah yang disepakati oleh para kiai sebagai langkah penyelesaian konflik sosial di Bujur Tengah.

Lima konsep tersebut dapat dijelaskan sebagai berikut: pertamamencari akar masalah penyebab carok massal. Konsep ini merupakan bentuk pengungkapan secara obyektif berbagai macam hal yang mengakibatkan terjadi carok massal. Mencari akar masalah berarti mengetahui secara obyektif latar belakang carok massal, dan siapa saja yang terlibat. Selain itu, mencari akan masalah bertujuan untuk mengetahui secara detail dan obyektif tentang mengapa carok massal itu terjadi. Dengan mengetahui hal-hal mendasar ini, maka dapat dipetakan penyebab, pihak terlibat, serta menjadi dasar pengambilan langkah berikutnya.

Dalam rangka mencari akar masalah penyebab carok massal ini, para kiai menghimpun informasi dari seluruh pihak yang dianggap mengetahui seluk beluk persoalan yang terjadi. Informasi itu dihimpun dari warga desa setempat, aparat pemerintah, kepolisian, TNI, serta warga yang dinggap pihak dari $\mathrm{H}$. Baidlowi maupun H. Mursyidin. Dengan cara ini, para kiai tidak hanya memperoleh informasi yang akurat, melainkan informasi yang diperoleh lengkap karena sumbernya dari berbagai pihak. Dari berbagai sumber, para kiai mengetahui bahwa akar masalah yang menyebabkan carok massal adalah 
sengketa tanah catoh.

Kedua berunding dengan warga untuk proses perdamaian. Konsep ini dimaksudkan untuk memastikan kesiapan warga desa Bujur Tengah dalam memadukan kesepahaman dengan para kiai, sebelum para kiai bertindak lebih jauh dalam upaya mendamaikan konflik itu. Perundingan dengan warga dalam soal ini, belum menynetuh hall teknis, melainkan masih dalam tataran pemahaman. Pemahaman yang diharapkan diperoleh dari perundingan ini adalah warga desa memiliki satu pemahaman bulat bahwa konflik ini harus diselesaikan dengan melibatkan para kiai. Pemahaman ini memiliki konsekuensi warga desa juga harus bisa bersepakat dengan para kiai terkait teknis perdamaian yang akan dilaksanakan.

Sebagaimana disampaikan di awal, bahwa proses perdamaian ini bermula dari keinginan warga desa untuk kembali kepada kehidupan sebagaiman sedia kala, maka tent unya konsesp ini pun dengan ringan dapat diterima oleh warga desa. Sehingga dalam perundingan ini, warga dan para kiai dapat menemukan kata sepakat tentang langkah-langkah berikutnya dalam proses perdamaian.

Ketiga "membeli" tanah catoh. Konsep ini didasarkan pada realita sumber penyebab carok massal adalah sengketa tanah catoh. Tanah catoh Bujur Tengah menjadi sengketa ant ara mantan kepala desa dan kepala desa terpilih yang berdampak terhadap warga desa yang lain. Oleh karenanya, menurut para kiai, sumber masalah dalam suatu konflik harus dilenyapkan terlebih dahulu, baru kemudian proses perdamaian dilanjutkan dengan teknis berikutnya. Menurut para kiai "membeli" tanah catoh harus dilakukan, karena dengan tanah cataoh itu "dibeli" (oleh para kiai), maka akan terjadi pemindahan penguasaan/hak/kepemilikan. Dengan begitu, maka setiap orang akan melihat bahwa tanah yanng disengketakan itu tidak lagi dapat disengketakan, karena sudah dalam penguasaan kiai. Sementara sebelumnya, warga desa sudah menyampaikan kata sepakat dengan para kiai, maka semakin tidak mungkin jika warga desa menunt ut kepada kiai soal tanah catoh.

Proses "pembelian" tanah catoh dapat disepakati oleh warga desa khususnya pemegang tanah catoh itu sendiri, karena warga desa sudah sangat paham, bahwa "pembelian" tanah catoh itu dilakukan oleh para kiai bukan untuk memiliki selamanya, melainkan hanya dalam waktu proses perdamaian. Jadi warga pun memahami bahwa jika tanah catoh itu masih menjadi hak milik seorang warga, maka pasti warga yang lain akan mempermasalakan itu, dan 
Ismail dan Moh Wardi: Peran Kiai dalam Rekonsiliasi Sosial Pasca Carok Massal di Bujur Tengah Pamekasan Madura (hal. 128-152)

akan menjadi sumber konflik kembali.

Keempat mengadakan koloman rutin. Konsep ini merupakan tindak lanjut dari langkah sebelumnya. Para kiai memahami bahwa di antara akibat dari konflik dan carok massal itu adalah put usnya jalinan silaturrahim atar warga. Karena pro kontra dalam konflik itu, warga desa menjadi terpecah dalam kelompok-kelompok. Akibatnya kemudian, komunikasi antar warga menjadi sangat terbatas, atau bahkan sama sekali tidak ada karena sikap bermusuhan itu. Nah dalam situasi ini, menurut kiai, harus ada media yang dapat membantu warga desa untuk kembali membangun komunikasi di antara mereka. Maka kiai berinisiatif mengadakan koloman rutin. Koloman rutin sendiri merupakan kegiatan pertemuan terbatas beberapa warga sekitar 30-40 orang yang dipimpin oleh seorang kiai dengan melaksanakan kegiatan dzikir, ditambahi dengan mau'idhatul hasanah, dan terkadang ditambah dengan tanya jawab tentang hukum Islam. Kegiatan ini dianggap efektif, menurut kiai, dalam mengembalikan jalinan shilaturrahim warga desa, karena beberapa koloman yang dilaksanakan akan memberikan kesempatan warga untuk bertemu dengan warga yang lain secara rutin. Koloman ini dilaksanakan seminggu sekali.

Dampak yang sangat diharapkan oleh para kiai dari koloman adalah terjadinya reinteraksi rutin antar warga yang sebelumnya sempat terput us akibat kenflik tersebut. Tujuan lain dalam bentuk meningkatkan spiritualitas warga memang tidak terelakkan, namun menjembatani interaksi dan sosialisasi antar warga menjadi target utama. Karena kegiatan seremonial (koloman) ini merupakan motivasi ekstrinsik bagi warga untuk kembali kepada jalinan shilaturrahim antar warga yang sesungguhnya telah terbina dari dahulu. Reinterkasi ini menjadi penting, juka karena carok massal itu telah memut us hubungan komunikasi antar pihak yang berkonflik, dan itu tidak hanya satu dua orang saja, melainkan hampir seluruh warga yang sudah terkotak oleh pro dan kontra terhadap salah satu pihak.

Sementara, koloman tersebut dibentuk oleh para kiai, selain memang memvitalisasi kolomanyang telah ada, bentukan kolomanbaru di masing-masing dusun untuk mengurai simpul-simpul polarisasi warga. Koloman di beberapa dusun dilaksanakan secara bergiliran. Sehingga reinteraksi dan rekomunikasi antar warga dari masing-masing dusun, untuk menuju lingkup kelompok yang lebih besar yakni desa. Karena kemudian koloman itu ditindaklajuti dengan kegiatan 
keagamaan skala desa, semisal peringatan Isra' Mi'raj Nabi Muhammad Saw, peringatan Maulid Nabi Muhammad Saw, kegiatan halal bihalal di bulan Syawal, dan beberapa kegiatan pengajian umum lainnya.

Dalam koloman di masing-masing dusun, reinterkasi dan rekomunikasi sebatas warga di dusun itu, tapi dalam peringatan hari besar Islam, seperti yang dicontohkan di atas, melibatkan hampir seluruh warga desa. Jadi reinterkasi dan rekomunikasi itu semakin meluas.

Kelima mendamaikan warga desa. Konsep ini dalam praktiknya ketika empat tahapan sebelumnya telah clearterlaksana, maka kemudian para kiai mempertemukan seluruh warga desa yang terlibat - langsung maupun tidak langsung - dalam konflik itu untuk memastikan bahwa perdamaian di antara mereka telah terwujud. Dari tahapan-tahapan sebelumnya para kiai telah dapat menilai bahwa uapay-upaya yang dilakukan telah membuahkan hasil, minimalnya warga desa telah aktif dalam seluruh kegiatan pendamaian serta menerima seluruh keputusan yang diambil secara kolektif. Jadi, warga desa dengan suka rela "menjual" tanah catoh yang mereka kuasai selama ini kepada para kiai, warga desa ikut aktif dalam perundingan-perundingan yang dilaksanakan, warga desa ikut serta dalam kegiatan koloman, maka semua itu menjadi indikator perdamaian akan segera dapat diwujudkan, setelah sekitar lima tahun para kiai dari peristiwa carok massal itu (tahun 2006-2010).

Maka langkah terakhir para kiai mempertemukan seluruh warga guna memastikan - kepada warga dan seluruh pihak, masyarakat maupun pemerintah dan aparat keamanan dan penegak hukum - bahwa warga desa Bujur Tengah telah damai. Bukan hanya pernyat aan atau kesimpulan para kiai soal perdamaian itu, melainkan juga masing-masing pihak yang berkonflik menyatakan sendiri akan wujud dari perdamaian itu, dan juga mereka bersedia berikrar atau bersumpah untuk terus menjaga perdamaian itu dengan cara tidak akan ada lagi siapapun yang akan mengungkit-ungkit masalah sengketa tanah catoh kepada siapapun. Serta juga, pernyataan itu kemudian dinyatakan dalam sebuah pernyataan bersama secara tertulis di hadapan seluruh masyarakat, para kiai dan aparatur pemerintah. Sehingga posisi perdamaian itu dapat dipertanggungjawabkan. Dan seluruh warga taslim(menerima) terhadap hasil perdamaian tersebut.

\section{Kiai sebagai Negosiator dan Mediator}

Peran negosiator dan mediator dalam proses rekonsiliasi atau perdamaian 
Ismail dan Moh Wardi: Peran Kiai dalam Rekonsiliasi Sosial Pasca Carok Massal di Bujur Tengah Pamekasan Madura (hal. 128-152)

konflik sosial, adalah mutlak keberadaanya. Begitu pula rekonsiliasi sosial pasca carok massal di Bujur Tengah. Kehadiran negosiator dan mediator dalam rekonsiliasi ini tidak dapat dielakkan. Sejalan dengan pembahasan pada bagian sebelumnya, bahwa rekonsiliasi sosial di Bujur Tengah diprakarsai oleh para kiai, bukan hanya itu, negosiasi dan mediasi dilaksanakan oleh para kiai. Sehingga keberadaan kiai sebagai negosiator dan mediator merupakan rententan peran yang dilakukan oleh para kiai.

Sebagaimana pada umumnya negosiator, kiai sebagai negosiator melaksanakan fungsi negosiasi dalam perundingan perdamaian para pihak yang berkonflik. Negosiasi adalah proses tawar-menawar dengan jalan berunding guna mencapai kesepakat an bersama ant ara satu pihak dengan pihak lain. Negosiasi juga diartikan suatu cara penyelesaian sengketa secara damai melalui perundingan antara pihak yang berperkara. Dalam hal ini, negosiasi merupakan komunikasi dua arah yang dirancang untuk mencapai kesepakat an pada saat kedua belah pihak memiliki berbagai kepentingan yang sama maupun yang berbeda (Nasikun, 1993). Nah, nah adalam posisi dan peran ini, para kiai melakukan beberapa hal, antara lain: (1) Kiai menjembatani pertemuan warga desa untuk berunding dan membicarakan banyak terkait dengan kepentingan mereka. (2) Kiai menawarkan beberapa konsep dalam perundingan-perundingan yang dilaksanakan untuk mencari solusi terbaik. (3) Kiai menjadi pengambil keputusan atas seluruh penawaran yang ada.

Karena dalam negosiasi yang terjadi adalah proses tawar menawar antar pihak yang berkonfli, maka tent unya kiai dalam negosiasinya menawarkan solusi-solusi tertentu, para pihak yang berkonflik juga demikian, kemudian diambil jalan tengah sebagai kesepatan sebagai solusi. Kiai memberikan usulan kepada warga bahwa tanah catoh akan "dibeli" oleh kiai dengan tujuan untuk menghilangkan sumber konflik dan kecemburuan sosial yang berakibat konflik, kemudian warga desa mempertimbangkan usulan tersebut. Di saat warga mearasa bahwa "pembelian' tanah catoh adalah jalan terbaik, maka kesepakatan pun diambil. Warga desa sepakat untuk "menjual" tanah catoh yang mereka kuasai selama ini kepada para kiai, sedangkan warga yang tidak menguasai tanah catoh bersepakat dalam hal ini untuk tidak mempermasahkan kembali tentang penguasaan tanah catoh itu.

Kiai sebagai mediator diperankan di saat terjadi deadlock dalam pengambilan keputusan. Pada saat "pembelian" tanah catoh oleh para kiai 
diputuskan dan disetujuan oleh sebagian warga desa, terdapat pula beberapa warga desa yang menolak dengan alasan, mereka tidak berkepentingan untuk "menjual" tanah catoh yang mereka kuasai. Di saat seperti inilah, kiai turun tangan untuk melakukan mediasi. Jadi, mediasi yang dilakukan oleh kiai, karena warga desa sudah terpolarisasi menjadi kelompok yang berbeda. Bukan hanya mereka yang terlibat konflik sebelum carok massal, namun di saat ini, kelompok warga terdiri dari mereka yang setujua untuk "menjual” tanah catoh, dan yang tidak. Maka kiai memediasi keduanya. Mediasi (Mediation), pihakpihak yang berkonflik bersepakat untuk menunjuk pihak ketiga yang akan memberikan nasihat-nasihat, berkaitan dengan penyelesaian terbaik terhadap konflik yang mereka alami bahwa mediasi merupakan salah satu bentuk negosiasi antara para pihak yang bersengketa dan melibatkan pihak ketiga dengan tujuan membantu demi tercapainya penyelesaian yang bersifat kompromistis (Nasikun, 1993).

Secara teknis, mediasi ini dilaksanakan oleh para kiai. Di sana para kiai mewakili pihak yang setuju "penjualan" tanah catoh, dan ada pula yang mewakili pihak yang tidak setuju. Ketidaksetujuan beberapa warga dalam "penjualan" tanah catoh ini hanya menyangkut soal harga. Menurut konsep awal, harga "pembelian" merupakan konpensasi at au ganti dari harga dulu di saat mereka membayar kepada H. Baildowi. Namun beberap warga mengusulkan untuk disesuaikan dengan harga sekarang. Deadlockyang terjadi baru dapat diselesaikan setelah mediasi dilakukan oleh kiai. Di mana kiai melakukan perundingan untuk membahas beberapa keinginan warga mengenai harga tanah yang akan "dijual". Jadi, mediasi yang dipernakan oleh kiai adalah untuk meluruskan konsep "pembelian" tanah catoh sesuai dengan rencana.

Di saat memediasi kedua kelompok, para kiai terlebih dahulu menjelaskan kepada warga bahwa tujuan dari "pembelian" tanah catoh bukan untuk memiliki at au untuk mencari keunt unngan sepihak. Melainkan, menurut kiai, jika objek sengketa bisa dihilangkan terlebih dahulu, maka penyelesaian konflik akan lebih mudah. Menghilangkan objek sengketa dengan cara pengalihan penguasaan at as tanah catoh dari warga kepada para kiai. Maka dengan demikian, para warga kemudian setuju terhadap "pembelian" tanah catoh oleh para kiai.

\section{Kiai sebagai EKsKutor}

Proses perdamaian di Bujur Tengah cukup menarik untuk diperhatikan. 
Ismail dan Moh Wardi: Peran Kiai dalam Rekonsiliasi Sosial Pasca Carok Massal di Bujur Tengah Pamekasan Madura (hal. 128-152)

Hal ini karena beberapa hal, antara lain; (1) warga pasrah penuh kepada kiai, (2) kiai sebagai konseptor, (3) kiai sebagai negosiator, (4) kiai sebagai mediator, (5) kiai sebagai ekskutor. Artinya, peran kiai dalam rekonsiliasi ini sangatlah mencolok. Dari penyusunan konsep, hingga aksi terakhir berupa melaksanakan seluruh keputusan yang disepakati, baik antar kiai, maupun keputusan dengan para warga desa.

Di sini, peran kiai tidak terbatas pada bagaimana merumuskan konsepkonsep yang praktis bisa diterapkan dan membuahkan hasil perdamain, melainkan juga, kiai harus menjadi pelaksana dari keputusan yang ditetapkan. Pertama keput usan tentang menghilangkan objek sengketa dari penguasaan warga yang menimbulkan konflik. Dalm hal ini, kiailah yang melaksanakan. Di sinilah kiai harus "membeli" tanah catoh. Di sinilah kiai harus mengeluarkan dana untuk "pembelian" itu. Kialah yang melakukan penawaran, pengecekan kondisi fisik tanah, dan lain sebagianya. Pada intinya, dalam hal menghilangkan objek sengekta dari penguasaan warga, di samping kiai telah merumuskan konsep dan strategi, kiai juga melaksanakan keputusan itu. Kiai harus mengekskusi keputusan yang di ambil.

Pada saat terjadi perbedaan pendapat antar warga tentang hal-hal teknis, kiai pun harus melakukan negosiasi at au bahkan mediasi kepada mereka agar keputusan bisa secepatnya dilaksanakan. Karena jika satu rencana atau rumusan tahapan dan proses rekonsiliasi terkendala, maka akan menghambat pada tahapan da proses selanjutnya. Oleh karena itu, maka para kiai berusaha untuk tahapan dan proses dapat berjalan sesuai rencana meskipun schedulenya harus berubah.

Terdapat beberapa keutungan at as peran kiai sebagai ekskutor, antara lain: (1) kiai memahami secara teknis atas rumusan konsep yang hendak diekskusi, karena kiai terlibat langsung dalam penyusunan konsep-konsep itu. (2) proses ekskusi terlaksana secara efektif dan efisien, karena warga sudah tahu betul tentang maksud dan tujuan para kiai, atau dengan kata lain, tidak akan ada penolakan yang berarti. (3) karakter kiai yang terbuka, membantu warga untuk berkomununikasi dengan kiai secara terbuka. Sehingga ekskusi tidak menjadi sesuatu yang menakutkan bagi para warga. Semisal, ketika pelepasan "kepemilikan" tanah catoh. Para warga yakin betul bahwa kiai sama sekali tidak punya maksud untuk mencari keuntungnan atas penyelesaian konflik ini. Meskipun mereka harus kehilangan "kepemilikan" atas tanah tanah catoh itu, 
namun mereka bersedia melaksanakan sebagaimana yang disepakati.

Berbeda dengan kejadian yang ekskusinya tidak dilakukan oleh para kiai. Keput usan pengadilan pun yang mendapatkan dukungan dari aparat keamanan, tidak mudah dalam pelaksanaanya, apa lagi menyangkut pengambilan hak. Namun, dalam kasus rekonsiliasi di desa Bujur Tengah, peran kiai dan pemahaman warga akan posisi dan fungsi kiai telah memuluskan proses ekskusi-ekskusi yang harus dilaksanakan.

\section{Model Rekonsiliasi Kultural Dalam Penyelesaian Konflik Sosial Pasca Carok Massal di Bujur Tengah PameKasan Madura}

Merujuk pada latar belakang terjadi konflik di Bujur Tengah, maka konflik tersebut disebabkan oleh kebutuhan manusia. Teori kebutuhan manusia (human needs theory) menjelaskan bahwa sebuah konflik terjadi karena adanya kebutuhan dasar manusia, berupa fisik, psikologi, ekonomi, sosial dan budaya, yang tidak terpenuhi. Menurut teori ini, konflik yang terjadi pada sebuah kelompok sosial disebabkan oleh keinginan manusia untuk memenuhi kebutuhannya, atau untuk memenuhi kepentingannya. Kepentingan yang ingin dicapai merupakan tujuan tertentu yang ingin diraih, baik di bidang ekonomi, sosial, politik, hukum, maupun budaya.

Dalam kasus konflik sosial di Bujur Tengah, peneliti menemukan bahwa konflik ini terjadi disebabkan oleh adanya kepentingan teretentu di antara yang berkonflik. Ada pihak yang berkepentingan memiliki sesuat u yang telah dikuasai pihak lain, dan ada pihak yang berkepentingan mempertahankan sesuatu yang mereka anggap milikinya. Pihak H. Baidlowi berusaha untuk mempertahankan tanah catoh yang menurut mereka adalah sudah menjadi hak miliknya, sedangkan pihak H. Mursyidin berusasha untuk memiliki tanah catoh karena mereka berhak terhadap tanah catoh itu, minimal selama memiliki kuasa unt uk itu. Karena adanya kepenting ini lah kemudian terjadilah konflik di antara mereka sehingga berujung pada terjadinya carok massal yang menelan korban luka-luka hingga jiwa.

Melihat proses perdamaian yang dilakukan oleh para kiai dalam menyelesaikan konflik di Bujur Tengah, dapat dipahami bahwa sedikitnya ada tiga pendekat an di dalamnya, (1) pendekatan ekonomi, (2) pendekatan religius, dan (3) pendekatan sosial-budaya. 
Ismail dan Moh Wardi: Peran Kiai dalam Rekonsiliasi Sosial Pasca Carok Massal di Bujur Tengah Pamekasan Madura (hal. 128-152)

Pertama, pendekatan ekonomi. Pendekatan ini terlihat pada bagian "pembelian" tanah catoh oleh kiai. Dalam pendekatan ini, unsur ekonomi sangat terasa, di mana para kiai tidak serta merta menggunakan kharismanya semata, melainkan juga melihat bahwa konflik itu juga dilat arbelakangi oleh kepentingan ekonomi, berupa penguasaan dan pengambilan hasil tanah catoh secara ekonomi. Tanah-tanah catoh itu merupakan lahan pertanian yang subur, jika dikelola dengan baik dapat memberikan hasil ekonomi yang signifikan bagi pengeloloanya, baik pertanian palawija, maupun tembakau yang merupakan hasil pertanian yang sangat menggiurkan bagi warga desa Bujur Tengah. Bagian inilah yang mendorong para kiai untuk menyelesaikan konflik dengan pendekatan ekonomi.

Para kiai memahami bahwa tanah catoh memberikan dampak signifikan terhadap taraf ekonomi pengelolanya. Sehingga sangat wajar jika tanah tersebut menjadi sumber sengketa. Maka dari itu, para kiai berpandangan bahwa kepentingan ekonomi ini harus diselesaikan terlebih dahulu. Opsi yang dipilih adalah mengalaihkan penguasaan at as atanah catoh tersebut. Dalam pengalihan ini, dibutuhkan pihak yang netral dan meyakinkan bagi warga bahwa pengallihan penguasaan bukan untuk mengambil unt ung, melainkan untuk mencari jalan rekonsiliasi dengan asumsi bahwa jika objek sengketa sudah berada di pihak lain, maka tidak ada alasan bagi para warga untuk mensengketakan tanah itu lagi. Sementara dalam pengalhan penguasaan tanah itu, pihak kiai hanya bertujuan untuk menegaskan kepada para warga bahwa para kiai akan menindaklanjti proses perdamaian setelah tanah catoh itu tidak menjadi ajang perebutan.

Para kiai juga mementingkan unsur ekonomi warga desa. Dalam hal ini para kiai bersepakat dengan warga bahwa yang berpindah adalah penguasaan tanah catoh, sementara pennghasilan warga dari tanah catoh itu akan tetap diperoleh sesuai dengan kesepakatan, karena pasca pengalihan penguasaan tanah catoh dengan cara "dibeli" oleh kiai, penggarapannya akan diserahkan kepada warga yang selama ini menggarap lahan itu. Sehingga hasilnya bisa dirundingkan, minimal bagi hasil separuh separuh. Bagian inilah yang juga melegakan warga sehingga para warga tidak keras kepala mempertahankan penguasaannya at as tanah catoh. Dan dengan cara ini pula, kondisi ekonomi warga bisa tetap stabil.

Kedua, pendekatan religius. Adanya pendekatan ini dapat dilihat pada 
bagian fugsi kiai sebagai da'i (penyebar ajaran Islam) (Dhofier, 2011: 41). Kiai senantiasa melaksanakn misi peneguhan dan penyebaran ajaran Islam kepada masyarakat. Sehingga dalam keterlibatanya menyelesaikan konflik sosial selalu menggunakan Islam sebagai pendekatan. Ajaran Islam diselipkan dalam setiap even adan moment. Tak terelakkan dalam rekonsiliasi sosial pasca carok massal di Bujur Tengah ini. Para kiai dengan cara "koloman" menggunakan anjaran Islam dalam merapatkan kembali hubungan sosial masyarakat yang sempat renggang akibat konflik. Dalam kegiatan koloman itu kiai mengajak warga desa untuk menguatkan keimanan dan ketakwaan kepada Allah Swt. Materi ini bertujuan agar warga yanng berkonflik tidak terlena dengan ego individual mereka. Para kiai mengajak warga agar memahami bahwa segala sesuatu yang diberikan Allah Swt kepada manusia adalah bertujuan untuk kebaikan manusia. Sehingga apapun bentuknya jika tidak memberikan kebaikan bagi individu dan orang lain, hendaknya ditinggalkan, atau minimal harus dapat dihindarkan dari merusak pihak lain. jadi koloman ini merupakan pendekatan religius yang diterapkan oleh kiai dalam rangka menyelesaikan konflik sosial di Bujur Tengah.

Ketiga, pendekatan sosial-budaya. Para kiai faham betul bahwa sesungguhnya masyarakat Bujur Tengah memiliki karakter persaudaraan yang kuat antar warga. Bagi warga desa Bujur Tengah, slogan taretan tongghal dara bukan sekedar unggkapan kata-kata, melainkan mengandung makna filosofi yang mendalam. Sesungguhnya bagi warga desa Bujur Tengah, setiap orang adalah saudara, setiap orang mempunyai ikatan darah, setiap orang memiliki hubungan baik yang harus dijaga. Oleh karenanya, maka warga desa Bujur Tengah mudah kembali kepada landasan filosofis itu, karena faktanya, kesan psikologis warga madura terhadap warga lainnya sangat erat. Masing-masing warga merasakan betapa mereka harus menjaga jalinan shilaturrahim di antara mereka. Nah, oleh karena itu, para kiai dengan menggunakan media koloman mudah sekali menyatukan kembali keakraban warga desa. Bukan hanya sekedar karena karisma kiai, melainkan juga didukung oleh faktor karakter warga itu sendiri. Karakter persaudaraan di antara sesama warga.

Para kiai tidak menafikan faktor sosial-budaya ini, karena karakter sosialbudaya warga desa Bujur Tengah sangatlah kental dalam beberapa bentuk. Keguyuban mereka dalam saling membantu di pertanian dan lainnya. Kondisi ini menjadi landasan sosial para kiai dalam menggunakan koloman sebagai media untuk membangkitkan semangat sosial warga desa. Dan pendekatan ini 
Ismail dan Moh Wardi: Peran Kiai dalam Rekonsiliasi Sosial Pasca Carok Massal di Bujur Tengah Pamekasan Madura (hal. 128-152)

sangatlah efektif, karena dengan koloman itu, komunikasi sosial warga desa kembali tumbuh dan terus berkembang sehingga dapat mengembalikan keguyuban mereka. Dan akhirnya berhasil mendamikan mereka. Mengembalikan kehidupan sosial mereka ke sedia kala. Kekerabatan, kekeluargaan, keakraban kembali terjalin di antara mereka. Para kiai berhasil menghilangkan rasa dendam di antara mereka. Para kiai berhasil menghilangkan agresifitas mereka dalam berebut tanah catoh. Secara tersirat perdamaian itu terlihat dari kerukunan, keguyuban, keakraban dan sikap positif sosial di antara mereka. Sedangkan secara tersurat perdamaian itu terbukti dengan dihasilkannya kesepakatan perdamaian berupa pernyataan dan perjanjian di atas kertas, menggunakan materai, di mana dengan perjanjian itu, mereka berjanji untuk tidak lagi mengungkit-ungkit masalah terkait di kemudian hari, oleh sebab dan tujuan apapun. Dengan begitu, perdamaian di desa Bujur Tengah pun terwujud.

Dari beberapa pendekatan yang diterapkan oleh kiai dalam rekonsiliasi sosial pasca carok massal di Bujur Tengah dapat digolongkan pada model rekonsiliasi kult ural. Model rekonsiliasi kultural yakni model rekonsiliasi dengan pendekatan kultural atau pendekatan budaya dengan terlebih dahulu dilakukan transformasi kesadaran melalui upaya-upaya pemaafan terhadap masa lalu untuk memperbarui hubungan (Nurcahyo, dkk., 2014: 71). Model pendekat an budaya lebih menekankan kepada aktifitas sosial yang berorientasi budaya dengan melibatkan kedua belah yang berkonflik (Nurcahyo, dkk., 2014: 72). Karena di dalam proses rekonsiliasi di Bujur Tengah para kiai berpedoman pada konteks budaya yang telah menjadi karakter masyarakat desa, yakni masyarakat yang memiliki keguyuban dan jalinan shilaturrahim dan persaudaraan yang kuat. Selian itu, para kiai menggunakan koloman sebagai bagian dari budaya masyarakat. Di mana dengan koloman itu, para kiai berupaya meningkatkan keimanan dan ketakwaan kepada Allah Swt, serta meningkatkan pemahaman tentang pentingnya perdamaian, persaudaraan dan kerukunan menurut padangan Islam.

\section{E. Simpulan}

Dari pembahasan di atas, dapat disimpulkan bahwa Konflik yang terjadi di Bujur Tengah, yang berujung pada terjadinya carok massal dilatarbelakangi oleh kepentingan atau kebutuhan tertentu di antara pihak yang berkonflik, sehingga secara teori konflik ini dapat dipahami dengan marujuk pada human 
|bU日" Jurnal Kajian Islam dan Budaya

needs theory. Peran kiai dalam rekonsiliasi konflik sosial di Bujur Tengah ini dalam beberapa bentuk, yakni; kiai sebagai konseptor, kiai sebagai negosiator, kiai sebagai mediator, dan kiai sebagai ekskutor. Model rekonsiliasi yang diterapkan kiai dalam pernyelesaian konflik di Bujur Tengah merupakan rekonsiliasi kultural dengan pendekatan ekonomi, religius dan sosial-budaya.

\section{Daftar Pustaka}

Arikunto, Suharsimi, 2002, Prosedur Penelitian. Jakarta: Rineka Cipta.

Azra, Azyumardi, 1999, Pendidikan Islam Tradisi dan Modernisasi Menuju Millenium Baru. Jakarta: Logos Wacana Ilmu.

Creswell, John W., 2010, Research Design: Pendekatan Kualitatif, Kuantitatif, dan Mixed. Yogyakarta: Pustaka Pelajar.

Denzin, Norman K. dan Yvonna S. Lincoln, 2009, Handbook of Qualitative Research, Penerj. Dariyatno dkk. Yogyakarta: Pustaka Pelajar.

Dhofier, Zamakhsyari, 1982, Tradisi Pesantren: Studi Tentang Pandangan Hidup Kyai. Jakarta: LP3ES.

Dhofier, Zamakhsyari, 2011, Tradisi Pesantren: Studi Pandangan Hidup Kiai dan Visinya Mengenai Masa Depan Indonesia. Jakarta: LP3ES.

Fisher, Simon. et.al., 2001, Mengelola Konflik: Keterampilan dan Strategi untuk Bertindak. Edisi Bahasa Indonesia. Jakarta: British Council.

Geertz, Cliffort, 2014, Agama Jawa: Abangan, Santri, Priyayi dalam Masyarakat Jawa Depok: Komunitas Bambu.

Horikoshi, Hiroko, 1987, Kiai dan Perubahan Sosial. Jakarta: P3M.

Jonge, Hubb De, 2011, Garam, Kekerasan dan Aduan Sapi. Yogyakarta; LkiS.

Karim, M. Rusli, 1985, Dinamika Islam di Indonesia: Suatu Tinjauan Sosial dan Politik. Yogyakarta: Hanindita.

Kuntowijoyo, 2002, Perubahan Sosial dalam Masyarakat Agraris, Madura 1850-1940, Terj. Mohammad Efendi \& Punang Amaripuja. Yogyakarta: Mata Bangsa.

Landman, Tood, 2003, Issues and Methods in comparative Politics: An Introduction. London: Routledge.

Marsh, D. and G. Stoker (eds), 1995, Theories and Methods in Political Sience. London: Macmillan.

Moleong, Lexi J., 2014, Metodologi Penelitian Kualitatif. Bandung: PT. Remaja Rosdakarya. 
Ismail dan Moh Wardi: Peran Kiai dalam Rekonsiliasi Sosial Pasca Carok Massal di Bujur Tengah Pamekasan Madura (hal. 128-152)

Muhajir, Noeng, 1996, Metodologi Penelitian Kualitatif. Yogyakarta: Rake Sarasin.

Nasikun, 1993, Sistem Sosial Indonesia. Jakarta: PT. Raja Grafindo Persada. Nizar, Samsul, 2007, Sejarah Pendidikan Islam: Menelusuri Jejak Sejarah Pendidikan Era Rasulullah Sampai Indonesia. Jakarta: Kencana.

Nurcahyo, Abraham, dkk., 2014, "Model Rekonsiliasi Kultural untuk

Mengatasi Konflik Sosial antar Perguruan Silat di Madiun”. Jurnal Studi Sosial, Th. 6, No. 2, Nopember.

Patoni, Achmad, 2007, Peran Kiai Pesantren dalam Partai Politik. Yogjakarta: Pustaka Pelajar.

Pawitra, Adrian, 2009, Kamus Lengkap Bahasa Madura Indonesia. Jakarta:

Dian Rakyat.

Qomar, Mujamil, 2007, Pesantren : Dari Transformasi Metodologi Menuju Demokratisasi Institusi. Jakarta: Penerbit Erlangga.

Ramadhan, Syahril, 2011, Analisa Pengaruh Struktur Audit, Konflik Peran, Ketidakjelasan Peran dan Pemahaman Good Governance terhadap Kinerja Auditor pada KAP di Jakarta. Aktiva Vol. 4, No. 7.

Ritzer, George, 2002, Sosiologi Ilmu Pengetahuan Berparadigma Ganda. Jakarta : PT Raja Grafindo Persada.

Rozaki, Abdur, 2009, Social Origin Dan Politik Kuasa Blater Di Madura. Yogyakarta:

Rukiati, Hj. Enung K. dan Fenti Hikmati, 2006, Sejarah Pendidikan Islam di Indonesia. Bandung: Pustaka Setia.

Sayfa, Auliya Achidsti, 2014, Eksistensi Kiai Dalam Masyarakat. Ibda'Jurnal Kebudayaan Islam. Vol. 12, No. 2, Juli - Desember.

Strauss, Anselm \& Juliet Corbin, 2003, Basic of qualitative Research, Grounded Theory Procedures and Techniques, terj. M. Shodiq. Yogyakarta : Pustaka Pelajar.

Subhan, Arif, 2012, Lembaga Pendidikan Islam Indonesia Abad ke-20 : Pergumulan antara Modernisasi dan Identitas. Jakarta: Kencana.

Sugiyono, 2008, Metode Penelitian Pendidikan: Pendekatan Kuantitatif, Kualitatif, dan $R \& D$. Bandung: Alfabeta.

Surahmad, Winarno, 1986, Dasar dan Teknik Research dengan Metodologi Ilmiah. Bandung: Tarsito. 
|bU日' Jurnal Kajian Islam dan Budaya

Soekanto, Soerjono. dan Soleman B. Taneko, 1985, Pengantar Konsep dan Teori Sosilogis. Bandar Lampung: Universitas Lampung.

Soetopo, Hendyat, 1999, Manajemen Konflik. Malang: UNM.

Soekanto, Soerjono, 2006, Sosiologi Suatu Pengantar. Jakarta: Raja Grapindo Persada, 2006.

Syarif, Zainuddin, 2014, Rekulturasi Pendidikan Islam Di Tengah Budaya Carok Di Madura. KARSA, Vol. 22 No. 1, Juni.

Taylor, J. dan Steven Bogdan, 1984, Introduction to Qualitative Research Methods: The Search for Meaning. New York: John Wiley dan son Inc.

Wiyata, A. Latief, 2002, Carok: Konflik Kekerasan dan Harga Diri Orang Madura. Yogyakarta: LkiS Yogyakarta.

Wahid, Abdurrahman, 2010, Menggerakkan Tradisi. Yogyakarta: LkiS.

Wirawan, 2010, Konflik dan Manajemen Konflik: Teori. Aplikasi, dan Penelitian. Jakarta: Salemba Humanika.

Majalah Tempo, 23 Juli 2006.

Majalah Tempo, 23 Juli 2006.

www.antaranews.com/.../lima-tersangka-pelaku-carok-massal-ditangkap. (diundul pada 1 Februari 2016. news.okezone.com/read/2015/../carok-massal-dipicu-aksi-penamparan www.antaranews.com/.../carok-berlatar-asmara-kembali-terjadi-di-sampa news.okezone.com/.../warga-2-kabupaten-di-madura-carok-4-luka-baco https://id.wikipedia.org/wiki/Carok. 